\title{
Bacterial Biodiversity from an Anaerobic up Flow Bioreactor with ANAMMOX Activity Inoculated with Swine Sludge
}

\author{
Aline Viancelli ${ }^{1}$, Airton Kunz ${ }^{2 *}$, Paulo Augusto Esteves ${ }^{2}$, Fernando Viçosa Bauermann ${ }^{3}$, \\ Kenji Furukawa $^{4}$, Takao Fujii ${ }^{5}$, Regina Vasconcellos Antônio ${ }^{6}$ and Matias Vanotti ${ }^{7}$ \\ ${ }^{I}$ Departamento de Ecologia; Universidade Federal de Santa Catarina; Florianópolis - SC - Brasil. ${ }^{2}$ Embrapa \\ Suinos e Aves; Concórdia - SC - Brasil. ${ }^{3}$ Departamento de Veterinária; Universidade Federal de Santa Maria; \\ Santa Maria - RS - Brasil. ${ }^{4}$ Department of Life and Environmental Sciences; Graduate School of Science and \\ Technology Kumamoto; University Kurokami, 2-39-1; Kumamoto - Japan. ${ }^{5}$ Department of Applied Life Science; \\ Faculty of Biotechnology and Life Science; Sojo University, 4-22-; 860-0082; Ikeda; Kumamoto - Japan. \\ ${ }^{6}$ Departamento de Bioquímica; Universidade Federal de Santa Catarina; 88040-900; Florianópolis - SC - Brasil. \\ ${ }^{7}$ United States Department of Agriculture, Agricultural Research Service; Florence - SC - USA
}

\begin{abstract}
The present study aimed to describe the bacterial community present at an anaerobic up flow bioreactor with ANAMMOX activity, inoculated with the sludge from the anaerobic pond of a swine slurry treatment system. The description was based on the molecular DNA techniques using primers for amplification of complete 16S rRNA gene and also new primers to amplify smaller fragments from $16 S$ rRNA. During the bioreactor operation time, the bacterial community changed significantly, increasing the nitrogen removal efficiency, reaching after 500 days a removal rate of $94 \%$. The complete PCR amplification of $16 \mathrm{~S}$ rRNA gene generated 17 clones, where three presented similarity with Candidatus Jettenia asiatica (97\%), twelve with Janthinobacterium (99\%) and two with uncultured clones. The PCR amplification of 436 base pairs had generated 12 clones, of which eight presented 96$100 \%$ similarity with Candidatus Anammoxoglobus propionicus, Planctomycete KSU-1 and one with Pseudomonas sp. (99\%) and three with uncultured clones.
\end{abstract}

Key words: ANAMMOX, anaerobic pond, sequencing, swine manure

\section{INTRODUCTION}

The biological nitrogen removal is an important biotechnological process with a high ecological and economical significance (Li et al., 2009). Discovered in the 1990s at an anoxic denitrifying pilot bioreactor of a wastewater treatment plant, Anaerobic Ammonium Oxidation (ANAMMOX) is an alternative nitrogen removal process, in which ammonium is oxidized to nitrogen gas $\left(\mathrm{N}_{2}\right)$ using as the electron acceptor, the nitrite, under anoxic conditions (Kartal et al., 2007).

The ANAMMOX process has advantages over the conventional processes for the combination of nitrification/denitrification such as reduction of oxygen demand and dinitrogen monoxide

*Author for correspondence: airton@ cnpsa.embrapa.br 
emission, as well decrease in sludge production in wastewater treatment plants (Kartal et al., 2010). The bacteria's responsible for the ANAMMOX process belong to the Planctomycete phylum which forms a large phylogenetic branch and includes genera such as Candidatus, Brocardia, Kuenenia, Scalindua, Anammoxglobus and Jettenia (Zhang et al., 2008).

Bacteria with ANAMMOX activity have been found in different bioreactors for effluent treatment, such as the completely autotrophic nitrogen removal over nitrite (CANON) bioreactor, the sequential batch bioreactor (SBR), and other wastewater treatment plants (Kuenen, 2008). They have also a significant role in nitrogen cycle for different natural ecosystems, such as freshwater, marine and sediment environments (Kartal et al., 2010).

Since ANAMMOX bacteria have low growth rate, it was not possible so far, to isolate them in pure culture. The molecular technologies are especially important for studying the ANAMMOX and the bacterial diversity in ANAMMOX related environments. In this context, the present work aimed to study the bacterial community by the phylogenic analysis of $16 \mathrm{~S}$ rRNA, present at an anaerobic up flow bioreactor with ANAMMOX activity, inoculated with sludge from the anaerobic pond of a treatment system for swine slurry and, also to develop a new primer set to amplify a smaller fragment from 16S rRNA, making molecular techniques easier, and improving the knowledge about the ANAMMOX bacteria.

\section{MATERIAL AND METHODS}

\section{Bioreactor and nitrogen analysis}

A 2-L bioreactor was inoculated with sludge (4 $\mathrm{g} / \mathrm{L}$ TSS), collected from an anaerobic pond from the experimental swine slurry treatment system, at Brazilian Agriculture Research Company (Embrapa Swine and Poultry), Concórdia, SC, Brazil (Schierhold Neto et al., 2006). The bioreactor was fed with the synthetic substrate prepared according to Schierhold et al. (2006), with $100 \mathrm{mgLid}$ of $\mathrm{NO}_{2}-\mathrm{N}$ and $100 \mathrm{mg} / \mathrm{Ld}$ of $\mathrm{NH}_{4}{ }^{+}-\mathrm{N}$ and kept at $\mathrm{pH}$ 8.0. The bioreactor activity was monitored by the analysis of $\mathrm{NH}_{4}{ }^{+} \mathrm{N}$, using ammonium selective electrode, $\mathrm{N}^{-\mathrm{NO}_{2}}{ }^{-}$and $\mathrm{N}$ $\mathrm{NO}_{3}{ }^{-}$determined by the Flow Injection Analysis System FIAlab 2500 (FIAlab Instruments, USA) with spectrophotometric detection system, provided with light source "LED" of tungstenhalogen (400 to $700 \mathrm{~nm}$ ), optical fiber $200 \mathrm{~mm}$ and UV/VIS detector USB4000 (Ocean Optics, USA) (Schierholt et al., 2006). To avoid the interference of oxygen in the process, $\mathrm{N}_{2}$ was bubbled until $0.5 \mathrm{mg} / \mathrm{L}$ of dissolved oxygen. The Hydraulic Retention Time (HRT) was adjusted between 18.5 and $24 \mathrm{~h}$. After 75 days of acclimatization, the bioreactor started to develop ANAMMOX activity (Schierhold et al., 2006). The bioreactor was monitored during the 500 days of operation, analyzing the nitrogen twice a week.

\section{Fluorescence in situ hybridization - FISH}

The samples were collected at days 20, 116, 250 and 500 from the bioreactor. The hybridization procedures were performed as previously described (Amann et al., 1995) and samples were fixed with para-formaldehyde (4\%). The fixed samples were hybridized with different probes (five) as shown in Table 1, and stained with DAPI. To determine the percentage of organisms, the amount of cells hybridized with specific probe were compared with DAPI stained cells. For visualization, an epifluorescence microscope (Olympus BX41, USA) was used.

\section{Sample and genetic material extraction}

At day 500 of operation, $0.01 \mathrm{~g}$ of red biomass was collected from the bioreactor. The biomass was applied to the FTA elute card (Whatman Bioscience, USA), and the genetic material was extracted from the card according to the manufacturer's instruction. The extracted solution was mixed two times with appropriate volume of phenol/chloroform/isoamylalcohol (50:48:2) and once with chloroform/ isoamylalcohol (96:4) to remove the proteins present in the solution as contaminants and dissolved phenol.

\section{Complete Amplification of 16S rRNA gene}

The complete amplification of 16S rRNA gene was performed using conserved eubacterial primers $6 \mathrm{~F}$ (5'-ggagagttagatcttggctcag-3') and 1492r (5'-ggttaccttgttacgact-3'). PCR parameters were 2 min initial denaturation at $94^{\circ} \mathrm{C}$, followed by 25 cycles of $15 \mathrm{sec}$ at $94^{\circ} \mathrm{C}, 30 \mathrm{sec}$ at $58^{\circ} \mathrm{C}$, and $30 \mathrm{sec}$ at $68^{\circ} \mathrm{C}$ (Viancelli et al., 2009).

\section{Amplification of 436 base pair (bp) fragments from 16S rRNA gene}

A forward primer 436F (5'-agcggtgaaatgcg-3') and a reverse primer 436R (5'-gggttcgctcgtta-3') 
were developed by amplifying a fragment of 436 bp between the 677-1112 bp from 16S rRNA region, having as development base a conserved region from Candidatus Brocadia anammoxidans nucleotide sequence deposited in Genbank (AF375994). The polymerase chain reaction was performed in a thermocycler (Eppendorf, UK), using the following parameters: 10 pmol each primer, 2.5 U of Taq Polimerase, 10\% PCR buffer, $2 \mathrm{mM} \mathrm{MgCl}, 200 \mu \mathrm{M}$ each dNTP, 3 ng DNA and ultrapure water in a final volume of $25 \mu \mathrm{L}$. The amplification was conducted in the following conditions: 3 min initial denaturation at $95^{\circ} \mathrm{C} ; 30$ cycles of $45 \mathrm{sec}$ denaturation at $95^{\circ} \mathrm{C}, 1 \mathrm{~min}$ annealing at $60^{\circ} \mathrm{C}, 1 \mathrm{~min}$ extension at $72^{\circ} \mathrm{C}$; and a final extension of $7 \mathrm{~min}$ at $72^{\circ} \mathrm{C}$. The amplified fragments were analyzed by $1 \%$ agarose gel electrophoresis, stained with Etidium Bromide (5 $\mu \mathrm{g} / \mathrm{mL}$ ), and visualized under UV light.

Table 1- Probe sequences and formamide concentration required for FISH.

\begin{tabular}{|c|c|c|c|}
\hline Probe & Specificity & Sequence & Form \\
\hline EUB MIX & All bacteria & $\begin{array}{l}\text { 5' -gctgcctcccgtaggagt-3' } \\
\text { 5'-cagccacccgtaggtgt-3' } \\
\text { 5'-ctgccacccgtaggtgt-3' }\end{array}$ & $20 \%$ \\
\hline Nso190 & All AOB & 5'-cgatcccetgettttctcc-3' & $55 \%$ \\
\hline NIT3 & Nitrobacter $\mathrm{sp}$ & $5^{\prime}$-cctgtgctccatgctccg-3' & \\
\hline $\mathrm{NEU}$ & Nitrosomonas sp & $5^{\prime}$-ccctetgctgcactcta-3' & \\
\hline AMX820 & $\begin{array}{l}\text { C.B. anammoxidans } \\
\text { C.K. stuttgartiensis }\end{array}$ & 5'-aaaaccctctacttagtgccc -3 ' & $40 \%$ \\
\hline
\end{tabular}

Cloning, sequencing and phylogenetic analysis of amplified fragments

The fragments amplified by PCR were purified using the GFX PCR and Gel DNA purification kit (GE Healthcare, UK). Purified fragments were inserted into $\mathrm{pCR}^{\circledR}$ 2.1-TOPO ${ }^{\circledR}$ vector (Invitrogen, USA) and transformed into DH5 $\alpha$ Escherichia coli competent cells (Sambrook et al., 2001). The clones were grown in Luria-Bertani medium plates supplemented with ampicillin $(50 \mathrm{mg} / \mathrm{ml})$. Colonies were chosen and the plasmidial DNA was extracted by alkaline method (Sambrook et al., 2001). The plasmids containing the fragments were analyzed with ABI3130 analyzer and BigDye terminator v3.1 cycle sequencing kit (Applied Biosystems, USA). Sequences were aligned using Clustal W 1.8.3 (Thompson et al., 1994) from BioEdit 7.0.5 package (Hall, 1999). After the alignment, the sequences were compared with the sequences from GenBank using BLAST tool (Altschul et al., 1990) and the phylogenetic analysis was conducted with software MEGA 3 (Kumar, et al., 2004).

\section{PCR detection limit}

To test the detection limit of the PCR that amplified the $436 \mathrm{pb}$, an ANAMMOX positive sample (confirmed by sequencing) containing $3 \mathrm{ng}$ of DNA, was diluted $\left(10^{-1}\right.$ until $\left.10^{-5}\right)$, submitted to
PCR and $1 \%$ agarose gel electrophoresis as described above.

\section{RESULTS AND DISCUSSION}

During the 500 days of operation, the bioreactor presented a maximum nitrogen removal rate of $1916 \mathrm{mg} \mathrm{N} \mathrm{L/d} \mathrm{(between} \mathrm{the} \mathrm{days} 400$ - 500 of operation). The value obtained represented $94 \%$ of nitrogen removal (Table 2) and was much higher than the traditional process of nitrification/denitrification, which removed about $300 \mathrm{mg} \mathrm{N} \mathrm{L/d}$. It was almost two times more than the removal by the sequential batch bioreactors and gas-lift with ANAMMOX activity $(1070 \mathrm{mg}$ $\mathrm{N}$ L/d) (Dapena-Mora et al., 2004). The stoichiometric index for $\mathrm{NH}_{4}{ }^{+}: \mathrm{NO}_{2}{ }^{-}: \mathrm{NO}_{3}{ }^{-}$obtained was 1:1.18:0.24 (Schierhold et al., 2006) that was similar to that found by Jetten et al., (2000) $1: 1.31: 0.22$.

The analysis of the bacterial community showed the presence of ammonium oxidizing bacteria from $\beta$-proteobacteria group (detected by NSO probe), Nitrosomonas spp (detected by NEU probe), Nitrobacter sp. and ANAMMOX (detected by NIT3 and AMX820 probes, respectively). Figure 1 showed that with the amount of organisms, the ANAMMOX activity increased along the operation days and, a decrease in the other bacterial populations occurred. Ammonium 
oxidizing bacteria (genus Nitrosomonas, Nitrosospira, Nitrosococcus, Nitrosovibrio, Nitrosolobus) were responsible for a little conversion of ammonium to nitrate or nitrite, explaining the difference found between the stoichiometric equation found in the reactor and the described in the literature.

The increase in the amount of organisms with anaerobic ammonium oxidation activity (Fig. 1) was in accordance with the nitrogen removal rate and ANAMMOX stoichiometry until day 250 . However, on day 500, the percentage of organisms decreased but the nitrogen removal rate increased. The reason of reduction of organism with ANAMMOX activity probably was due to the sampling procedure since the reactor did not have a homogeneous distribution of these organisms.

Table 2 - Highest values of nitrogen loading, removal and \% removal performed during the 500 days of operation of the reactor.

\begin{tabular}{cccc}
\hline Days & nitrogen loading rate (mg N L/d) & nitrogen removal rate $(\mathbf{m g} \mathbf{~ N ~ L / d )}$ & nitrogen removal (\%) \\
\hline $0-100$ & 305.6 & 191.3 & 59 \\
$100-200$ & 597.0 & 535.5 & 89 \\
$200-300$ & 744.0 & 638.8 & 85 \\
$300-400$ & 1404.9 & 1245.7 & 88 \\
$400-500$ & 1653.2 & 1569.9 & 94 \\
\hline
\end{tabular}

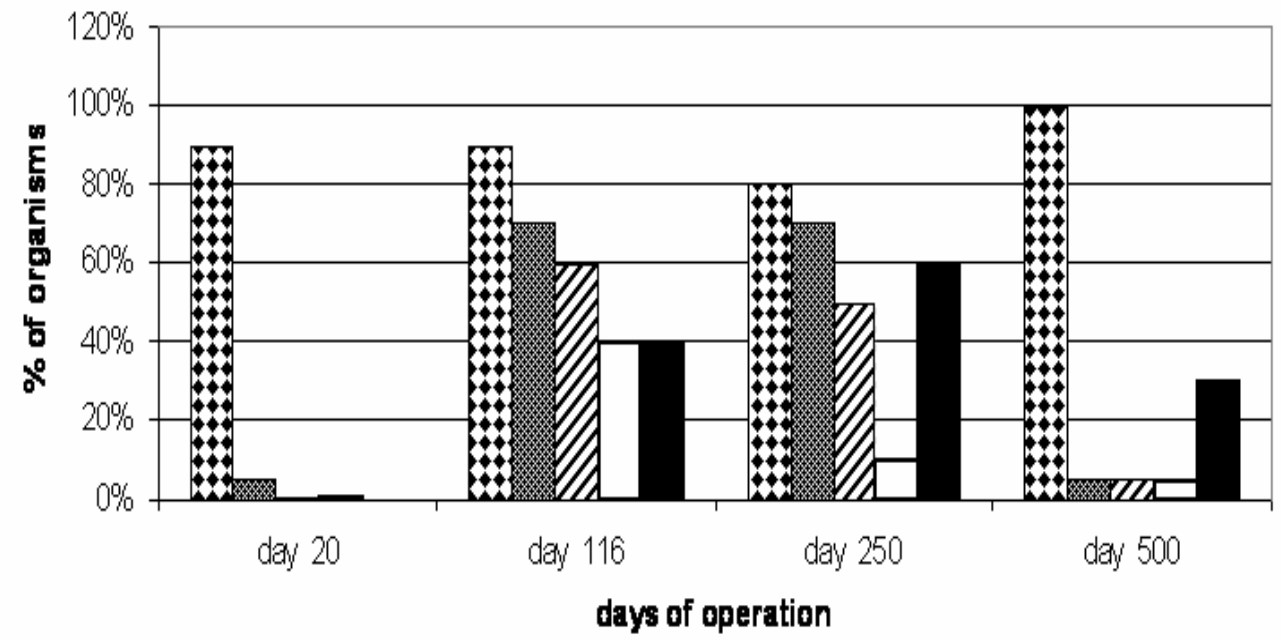

aEUB mix 圆N50190 aNEU aNT3 AMX820

Figure 1 - Bacterial diversity present in the bioreactor, analyzed by FISH during the 500 days of bioreactor operation. Probes detected total eubacteria (EUB mix); $\beta$-proteobacteria group (NSO 190); Nitrosomonas spp (NEU); Nitrobacter sp. (NIT3) and ANAMMOX (AMX820).

Since the stoichiometric index, removal rate and FISH analysis showed the presence of organisms with ANAMMOX activity, molecular techniques of PCR and sequencing were performed to amplify and characterize the ANAMMOX species present in the bioreactor. A complete PCR targeting for 16S rRNA gene was performed and the fragments amplified were cloned and sequenced. From the 17 clones obtained from the $16 \mathrm{~S}$ rRNA, 12 presented 99\% similarity with Janthinobacterium sp. (sequences FJ225383, FJ225384 and FJ225385) and were aerobic facultative nitrate-reducing bacteria, typically present in the soil and water. Although these were aerobic organisms, they had been isolated in aerobic and anaerobic conditions. Organisms with $99 \%$ similarity to 
Janthinobacterium were found in a microbial ammonium-assimilating community in animal waste treatment systems (Sasaki et al., 2005).

Three clones (sequences FJ225387 and FJ225388) presented $97 \%$ similarity with ANAMMOX Candidatus Jettenia asiatica and strain Planctomycete KSU-1 and 94\%, 92\% and 91\% with Candidatus Anammoxoglobus propionicus, Candidatus Brocadia anammoxidans and Candidatus Kuenenia stuttgartiensis, respectively. From these three clones, two showed exactly the same nucleotide sequence (FJ225387), and the FJ225388sequence showed only a single base difference with that (FJ225387). These two clones were named Brasilis concordiensis 1 and 2 (Viancelli et al., 2009).

Parallel to the amplification of 16S rRNA gene, a PCR targeting a $436 \mathrm{bp}$ region was performed.
Figure 2A shows the results of PCR standardizing with a specific 436 bp amplification. The amplified fragment was sequenced and confirmed the ANAMMOX similarity. This DNA sample was used as PCR positive control. After the standardizing, the technique was performed to test the limit of detection using an initial amount of 3 ng of DNA. The DNA was serially diluted (from $10^{-1}$ to $10^{-5}$ ) and submitted to PCR. Figure 2B showed that the last amplification occurred with $0.3 \mathrm{ng}$ of genetic material, which was less than the used in other studies: 30 to $80 \mathrm{ng}$ (Penton et al., 2006). This indicated that the PCR described here could be performed with low quantities of DNA, which would be very interesting, considering the low amount of ANAMMOX bacteria found in natural environment samples.
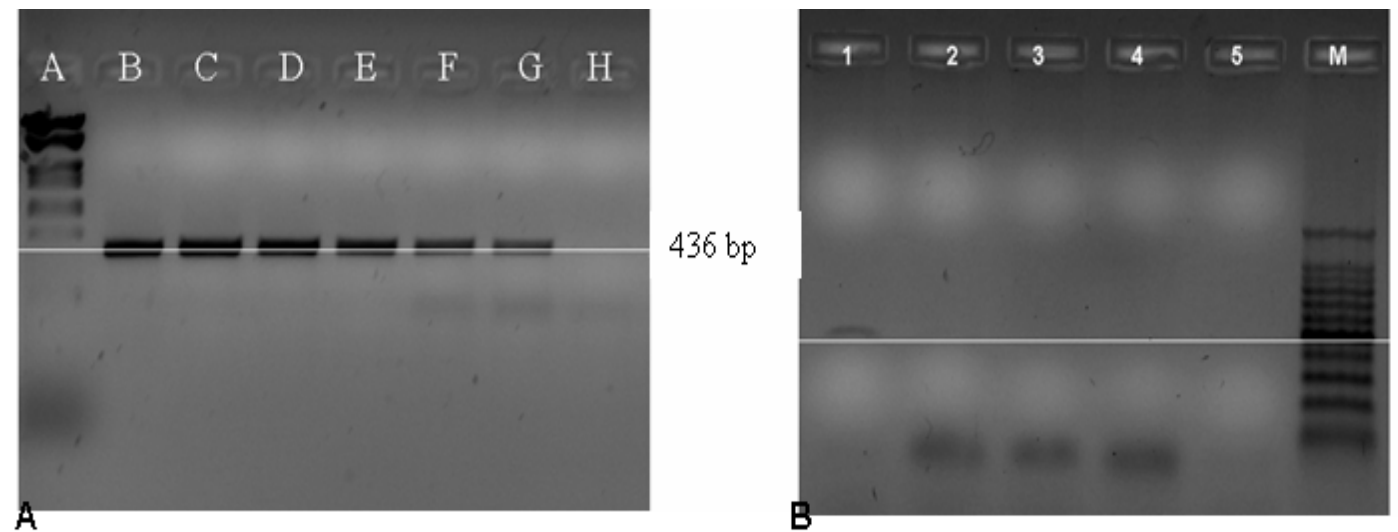

$436 \mathrm{bp}$

Figure 2 A - PCR standardizing with new primer set: A: 100 bp Latter; B-G samples with 3ng of DNA; H: negative control. B: PCR with serial DNA dilution to test the primers limit of detection: 1: dilution $10^{-1} ; 2$ : dilution $10^{-2} ; 3$ : dilution $10^{-3} ; 4$ : dilution $10^{-4} ; 5$ : dilution $10^{-5}$; M: DNA ladder $100 \mathrm{bp}$.

The biomass samples from the bioreactor were submitted to PCR and the amplified fragments of $436 \mathrm{pb}$ were cloned and sequenced. This generated 12 clones, eight similar with ANAMMOX organisms (sequences GQ850472, GQ850476, GQ850473, GQ850479 and GQ850478), Candidatus Anammoxoglobus propionicus (100\%), Planctomycete KSU-1 (96\%), Candidatus Jettenia asiática (98\%) (Fig. 3).

Candidatus Anammoxoglobus propionicus was found in a culture medium enriched with oxidizing propionate, acetate and formate with nitrate as final acceptor of electrons. Candidatus
Anammoxoglobus propionicus was the first ANAMMOX bacterium with defined niche. The oxidation of propionate and ammonium when at a mixed culture, presented competitive behavior with ANAMMOX and other denitrifying heterotrophic bacteria by the oxidation of propionate in the presence of ammonium, nitrite and nitrate. After four months of Candidatus Anammoxoglobus propionicus culture, according to Kartal et al. (2007), they eliminated other ANAMMOX species (Brocadia anammoxidans) from the reactor. 


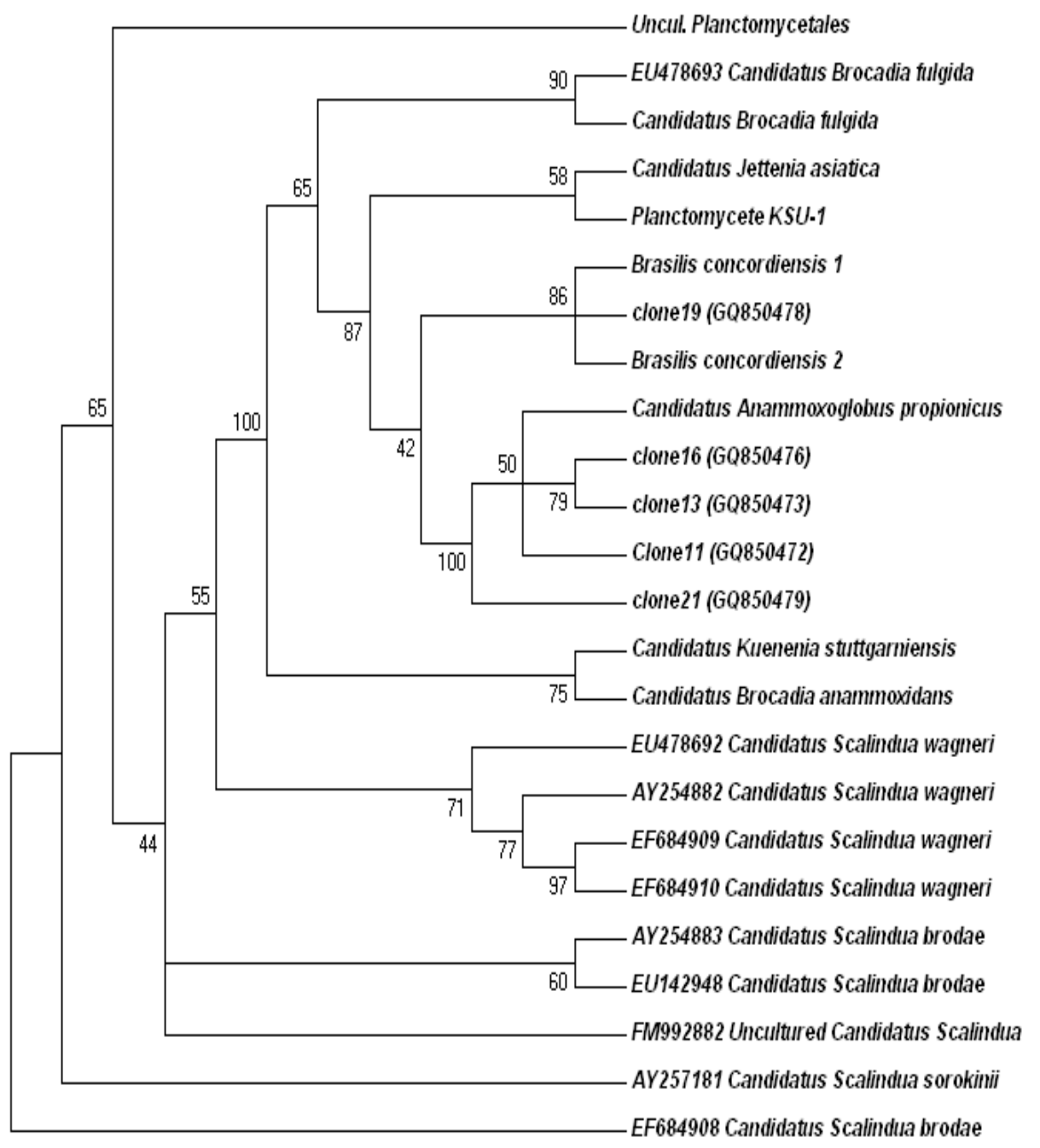

Figure 3 - Dendogram of sequences found in the present study (GQ850472, GQ850476, GQ850473, GQ850479, GQ850478) and sequences from other studies deposited in GenBank.

Planctomycete KSU-1 was identified as the dominant bacteria species in a biofilm ANAMMOX reactor with an average totalnitrogen removal rate of $984 \mathrm{mg} \mathrm{N} \mathrm{L/d} \mathrm{(Fujii} \mathrm{et}$ al., 2002) and presented $92 \%$ similarity with Candidatus Brocadia anammoxidans. Although it was not classified as an ANAMMOX organism, Planctomycete KSU-1 probably was a new member of Brocadia genus. In other studies, Candidatus Jettenia asiatica was described as the dominant bacteria in a granular sludge ANAMMOX bioreactor, where AAOB were also found belonging to $\beta$-Proteobacteria. The nitrogen removal rate of the reactor was $800 \mathrm{mg} \mathrm{N} \mathrm{L/d}$ (Quan et al., 2008), somewhat lower comparied to the removal rate obtained in this study (1916 mg N L/d).

One clone (sequence GQ850474) showed 99\% similarity with Pseudomonas sp. These are denitrifying bacteria that under anaerobic conditions use nitrate as final acceptor electrons and have been found on SBR reactors converting all $\mathrm{NO}_{3}^{-}$in the medium to $\mathrm{N}_{2}$ (Merzouki et al., 1999). Three others had similarity with uncultured bacterium clones isolated from the swine sludge. In the present study, two similar ANAMMOX organisms (Candidatus Jettenia asiatica and Candidatus Anammoxoglobus propionicus) were identified at the same time in the bioreactor. However, Kartal et al. (2007) when working with 
enrichment culture concluded that two ANAMMOX species rarely were found in the same place, or in the same bioreactor. This could be explained because the bacterial community analyzed in the present study was not from a pure culture and the species were still competing. Probably, in due course of time, one might get eliminated by competition as reported by Kartal et al (2007). Considering the above, it was possible to conclude that the PCR developed could be easily applied in monitoring the ANAMMOX bacteria, because its protocol procedures and high capacity to detect little DNA amount, permitted that. By the high performance in nitrogen removal rate, ANAMMOX could be a powerful and cheap technology to treat the sludge rich in ammonium like swine sludge.

\section{REFERENCES}

Amann R.I.; Ludwig W.; Schleifer K.H. (1995), Phylogenetic Identification and In Situ Detection of Individual Microbial Cells without Cultivation. Microbiol Rev., 59, 143-169.

Altschul, S.F., Gish, W., Miller, W., Myers, E.W. and Lipman, D.J., (1990), Basic local alignment search tool. J. Mol. Biol., 215, 403-410.

Dapena-Mora, A.; Campos, J.L.; Mosquera-Corral, A.; Jetten, M.S.M.; Méndez, R.. (2004). Stability of the ANAMMOX process in a gás-lift reactor and a SBR. J. Biotechnol., 110, 159-170.

Fujii, T.; Sugino, H.; Rouse, J.D.; Furukawa, K.. (2002), Characterization of the microbial community in an anaerobic ammonium-oxidizing biofilm cultured on a nonwoven biomass carrier. J. Biosci. Bioeng., 94, 412-418.

Hall, T.A. (1999), BioEdit: a user-friendly biological sequence alignment editor and analysis program for Windows 95/98/NT., 41, 95-98.

Jetten, M.S.M; Wagner, M.; Fuerst, J.; Van Loosdrecht, M.; Kuenen,G.; Strous, M. (2000). Microbiology and application of the anaerobic ammonium oxidation (anammox) process. Curr. Opinion Biotechnol., 12, $283-288$.

Kartal, B.; Kuenen , J. G.; van Loosdrecht, M. C. M. (2010), Sewage Treatment with Anammox. Science., 328, $702-703$.

Kartal, B.; Rattray, J.; Van Niftrik, L.A.; Van De Vossenberg, J.; Schmid, M.C.; Webb, R.I.; Schouten, S.; Fuerst, J.A.; Damsté, J.S.; Jetten, M.S.M.; Strous, M.. (2007), Candidatus Anammoxoglobus propionicus a new propionate oxidizing species of anaerobic oxidizing bacteria. Syst and Appl Microbiol., 30, 39-49.
Kuenen, J. G. (2008), Anammox bacteria: from discover to application. Nature., 6, 320-326.

Kumar, S.; Tamura, K.; Nei, M.. (2004), MEGA 3: Integrated software for molecular evolutionary genetics analysis and sequence alignment. Brief. Bioinform., 5, 150-163.

Li, X.R.; Du, B.; Fu, H.X.; Wang, R.F.; Shi, J.H.; Wang, Y.; Jetten, M.S.M.; Quan, Z.X. (2009), The bacterial diversity in an anaerobic ammoniumoxidizing (ANAMMOX) reactor community. Syst and Appl Microbiol., 32, 278-289.

Merzouki, M.; Delgenès, J.P.; Bernet, N.; Moletta, R.; BenlemLih, M.. (1999), Polyphosphate Accumulating and Denitrifying Bacteria Isolated from AnaerobicAnoxic and Anaerobic-Aerobic Sequencing Batch Reactors. Cur Microbiol., 38, 9-17.

Penton, C.R; Devol, A.H.; Tiedje, J.M.. (2006), Molecular Evidence for the Broad Distribution of Anaerobic Ammonium-Oxidizing Bacteria in Freshwater and Marine Sediments. Appl. Environ. Microiol., 72, 6829-6832.

Quan, Z.; Rhee, S.; Zuo, J et al., (2008), Diversity of ammonium-oxidizing bacteria in a granular sludge anaerobic ammonium-oxidizing (ANAMMOX) reactor. Environ Microbiol. Doi: 10.1111/j.14622920.2008.01642.x

Sambrook, J.; Russel, D.W. (2001), Molecular Cloning: A laboratory Manual. New York, Cold Spring Harbor Laboratory Press.

Sasaki, H.; Sasaki, T.; Nakai, Y. (2005), Ammoniaassimilating microbes in the animal waste treatment systems. J integr fiel sci., 2, 95-106.

Schierhold Neto, G. F.; Kunz, A.; Vanotti, M.B.; Soares, H.M.; Mattei, R.M. (2006), Aclimatação e acompanhamento da atividade de lodos de efluentes de suinocultura para remoção de nitrogênio pelo processo de oxidação anaeróbia de amônia (ANAMMOX). Paper presented at $30^{\text {th }}$ Congreso Interamenricano de Engenieria Sanitaria y Ambiental. Punta del Este, Uruguay.

Thompson, J.D.; Higgins, D.G.; Gibson, T.J. (1994), CLUSTAL W. Nucleic Acids Res., 22, 4673-4680.

Viancelli, A.; Kunz, A.; Esteves, P.A.; Nishiyama, T.; Fujii, T.; Vanotti, M.; Antonio, R.V.. (2009), Analysis of bacterial community from a sludge reactor with anammox activity . Paper presented at $1^{\circ}$ Simpósio Internacional sobre gerenciamento de resíduos de animais, 11-13 March, Florianópolis, Santa Catarina.

Zhang, L.; Zheng, P.; Tang, C.; Jin, R. (2008), Anaerobic ammonium oxidation for treatment of ammonium-rich wastewaters. J Zhejiang Univ Sci., 9, 416-426.

Received: June 25, 2010; Revised: October 27, 2010; Accepted: July 01, 2011. 


\section{PÁGINA EM BRANCO}

